\title{
Comparing Selected Levels of Communication Between Fiancée, Fiancé and Spouses
}

\begin{abstract}
A man, coming to the world in a family community, reaches maturity and in most cases sets a family of his own. Traditional transition from the family of origin to family of procreation combines with engagement followed by marriage as a family subsystem. These periods characterize with high dynamics of changes taking place within the marital subsystem. Bride and groom, and later married couple face the need to discuss family matters, negotiate marital roles, develop compliance and their identity, regulate marriage intimacy, solve conflicts, as well as, run their household. Undoubtedly, planning and organizing life requires developed communication skills. The author, guided by these premises, has sought to present some aspects of communication for engaged couples and spouses with many years of experience. Isolated groups were not accidental. Main reason was the ability to analyze the results in terms of convergence and divergence of views and assessments shown by brides and married couples at different stages of marriage - family life. Therefore, structure of this text was built by the following variables' categories: frequency of conversations in the family and their themes, communication barriers between spouses and fiancés, ways of improving the flow of information between partners.
\end{abstract}

Key words: communication, family, stages of marital life, marriage, engagement period.

\section{Introduction}

It is difficult to imagine life in a familiar environment, neighbourhood, and local or supralocal environment without communicating with their members. The process of communication between people - society members - is a specific interaction [Dobek-Ostrowska 2004, p. 11], allowing for making some of the 


\section{Barbara Lulek}

contents common. The sender and the recipient [Harwas-Napierała 2008, pp. 13-14], who are able to clearly define themselves and their opinions, as well as to listen to others effectively, cooperate and then build social relations based on partnership [Nęcki 1992, p. 12].

It is impossible to call a direct communication between the individuals [Dobek-Ostrowska 2006, p. 62] a state or a situation. It is an uninterrupted activity between these entities [Mrozowski 2001, p. 16.] pursuing common goals and experiencing the direct effects of actions taken. Open and deep interpersonal communication promotes the transfer of intellectual content knowledge, information, ideas but it also creates a kind of mental space in which the individuals exchange ideas, learn about emotions and feelings [Pisarek 2008, pp. 17-18], interpret events and symbols [Denek 2002, p. 123] on both, verbal and non-verbal level of communication [Kiezik-Kordzińska 2004, p. 34, Stewart , Logan, 2003, pp. 81-94, Argyle 1999, pp. 90-93, Głodowski 2001, pp. 36-44, Domachowski 1993, pp. 29, Morreale, Spitzberg, Barge 2007, pp. 181-185, McKay, Davis, Fanning 2001, pp. 68-69]. Thus, communicating means creating a kind of common space [Pisarek 2008, p. 7], filled with transmitted information and emotions, verbal symbols, as well as with an area of creating common concepts and opinions [Harwas-Napierała 2006, p. 15]. Communicating also means exchanging experience and common action based on defining and redefining the relationship between sender and recipient [Dobek-Ostrowska 2004, p. 14].

Therefore, interpersonal communication is a highly complex process. It is performed through verbal and non-verbal transmission, it includes intentional transmission of specific information and emotions, as well as proportions between sender and recipient [Harwas-Napierała 2006, p. 15.]. To continue this thought, it is necessary to point out three basic components forming communicational process: the sender, the transmission and the recipient. The subject literature point to subjective/objective approach to the aspect. The sender, or communicator and transmission's source, is a communicational subject. This means that by constructing or expressing the statement, the sender is directly or indirectly responsible for the transmission's contents. Intellectual and emotional content transferred between the sender and the recipient is the transmission or information, signal and sign. Whereas, the recipient concentrates on receiving and understanding the transferred content [Pisarek 2008, p. 20]. Communication provokes certain effects and specific types of feedback [Filipiak 2004, p. 30]. Proper communication encourages forming open attitude between people. It makes people concerned with other people's needs, interested in other units, ready to make changes in activities done in other people's favour [Winiarski 2000, p. 130], as well as makes people understand their partners, feel empathy for other people and sort of walk in their shoes [Rutkowiak 1992]. Only the foundation of 
co-experiencing can form a close socio-emotional relation between individuals, enriched with empathy factor. It is then not only the communication between units but a full personal dialogue [Winiarski 2000, p. 131] proceeding on three levels: personal, existential and material. The dialogue's purpose is to unite people through manifesting their feelings, giving themselves to the partners, as well as relating to the outside world [Tarnowski 1991].

\section{Marital and family communication compared to family life stages}

Getting married is a very important step in each person's life, for in some perspectives it connects with having offspring and creating family community. Generally speaking, marriage refers to a certain family subsystem created by two adults, who come from two different generational families, and who bonded permanently - in their intention - to live together [Plopa 2008, p. 51].

The marriage combines with the whole range of activities to put the relationship between the spouses and families of origin in order. Therefore, partners are to be prepared for a number of tasks in order to determine marital and family issues, define marital identity, run the household and create the emotional climate in marriage. The new couple has to determine its own place among friends and communities, as well as indicate the inter-generational ties to the family. This background creates another task for the spouses, i.e. being a life partner for the other person, as well as fulfilling mutual expectations. Keeping the satisfactory balance between intimacy and individuality, spouses build a solid foundation for their family future.

Engagement period, proceeding the marriage is of a great importance for a properly functioning family. During this period the future spouses get to know each other, build a real picture of themselves, verbalize their own expectations, as well as outline the vision of a common life. According to A. Zielonacki [1982, p. 11], this aspect is significantly important in order to prepare well for legalizing the relationship. Getting to know the spouse's family of origin and deepening the emotional bound between the partners are widely recognized and performed tasks in the engagement period. The engagement itself comes in various forms in modern times. Thus, the literature describes quasi-traditional, façade and personal engagement, as well as lack of engagement [Muszyński, Sikora 2008, pp. 332-333.].

It is quite obvious that during preparation period and after getting married, the spouses function in mutual communication space, which includes significant and everyday issues, is used to exchange information and radically influences relationship quality. Exchanging the sender and the recipient roles between partners favours negotiations, defining various family problems, building commitment and creating own identity, and relationship's identity [Plopa 2005, p. 120]. 


\section{Barbara Lulek}

When communicating, spouses and fiancés exchange information about their feelings, needs, experience, life plans and everything else which concerns relationship between spouses. This factor highly influences the quality of relations connecting the spouses, especially emotional bond, showing how far do they trust each other and their bond of sympathy. This factor reflects marriage's emotional climate and level of commitment to marital life [Harwas-Napierała 2008, p. 61].

The need for communication in the family is standing. Family members operate interchangeably as a sender and receiver of verbal and non-verbal messages. However, communication form varies depending on different stages of family life, usually accompanied by a specific situational context, associated emotions and adopting appropriate attitude [Rostowska 2008, p. 89]. According to the research, young couples are more likely to seek solutions to conflicts and above all to admit their existence. The couples often change the way they argue, however, they are far from showing extreme patterns of behaviour. Middle-aged couples are less likely to reveal conflicts than young couples. These couples function between the most old-age couples' passivity and young couples intense style of communication. Therefore, their communication style can be described as indirect. Middle-aged couples usually use a very neutral language while discussing directly the conflicts. Pensioners' couples evaluate their marital problems as insignificant, at the same time presenting extreme patterns of arguments or kindred spirits. These couples' conversations are quiet with a small or none indication to a conflict [HarwasNapierała 2008, p. 67].

Young marriages lay their marriage foundation on feelings and fascination, whereas older couples change fascination into attachment. Older marriages evaluation in based on their experience rather than future image. Moreover, senior marriages lay their foundation on mutual tolerance, attachment, habit and the ability to forgive, etc., and their communication issues are replaced by attachment and duration standards [Harwas-Napierała 2008, p. 68].

Therefore, spouses' communication can be positive or negative. In the first case, spouses' positive attitude favours mutual attention to actually listen to the statement. Moreover, it deepens family ties, sense of community, intimacy, enlarge the chance for spouses to get to know each other and favours frequent and satisfactory information exchange. The second case consequences are defensive behaviours shown by spouses [Rostowska 2008, p. 89].

Writing about marriage and fiancés communication, the author simply cannot overlook the ability to formulate clear and legible messages issue, as well as openness and honesty issues which are the foundation of a successful and happy union between two people. It is about the ability to disclose authentic, sometimes negative experience and to transfer them to another person, as well as about the ability to receive the content transmitted by the partner. 
In the process of real communication and dialogue, fiancés and spouses support themselves in everyday hardship or in overwhelming situations by creating an undisturbed space where all family members can experience themselves.

Although, dialogue relations are significant to marriage and engagement period because they condition the quality of relations between people in this social group, especially emotional ties, mutual trust and sympathy measure as well as family emotional climate and the degree of individuals' commitment into marital-family life, many modern families lack in the relations [Harwas-Napierała 2008, pp. 61-62].

There are many factors disturbing the real exchange of information about feelings, needs, experience, life plans and everything else that concerns relations between spouses and other people creating family [Rostowska 2008, p. 89]. They derive from certain spheres of familiar or partner life like presented values, divergent expectations, concentrating too much on freedom and partner's independence in the relationship, different life plans or financial issues, but they also lie in a working place or study [Mc Kay, Davis, Fanning 2002, p. 230]. These conditions disturb family and marital communication, i.e. generate dysfunctional communication patterns, controlling and dominant communication strategies [Plopa 2005, pp. 120-122], inappropriate ways of solving problems, lack of understanding [Poręba 1981, p. 17] or commitment into the conversation and loneliness. They are of different forms, their range and degree of influence on family members' development also vary. Moreover, they cause emotional, verbal and behavioural disturbance in communication [Laskowski 1985, pp. 178-185]. These disturbances lead straight to family community disintegration or even to its breakdown [McKay, Davis, Fanning 2002, p. 229].

\section{Research draft}

In order to present the changes in the way partners build communication relations between them, the author undertook the issue of interpersonal communication in a family - during engagement period and marriage and described the process in the dynamic frame. It was assumed that the process of information flow between relatives is conditioned by many endogenic and exogenic factors. Some of the factor are: sex, level of intellectual, emotional, social-moral and personal development, social behaviour and cultural patterns, family ties, fulfilled roles, family's financial conditions and social contacts [Rostowska 2008, p. 89]. Seniority of living together was also recognised as a factor differentiating communication process among married couples and fiancés. Therefore, the author aimed in recognising what are the ways of communicating among engaged couples and spouses being married for 15 years. Many questions were answered in the course of research, however the author limited the following study to 


\section{Barbara Lulek}

presenting selected communicational aspects determined by the following research issues: What is the subject matter appearing in fiancés and spouses' conversations? How often do the respondents talk in various stages of marriagefamily life? What communicational barriers do the spouses and fiancés notice in sending the information? The empirical data was presented in comparative way, in order to fully illustrate answers to these questions.

The empirical research was conducted in 2010 and 2011 in Rzeszow and Krosno district, Podkarpacie province. People for the research test were chosen with random-purposive sampling to construct two equal test groups. There were 25 engaged couples in the first group and 25 married couples in the second, overall, there were 100 people (50 fiancés and 50 spouses married for 15 years). Family counselling services founded at roman-catholic parishes in Rzeszow and Krosno were very helpful.

The study group had diverse but rather high level of education. Half of the fiances and spoused declared to have finished upper secondary or technical school, while there were $36 \%$ of fiances and $20 \%$ of spouses having a universiy education. Nearly one fifth of each group indicated to have finished a vocational school.

The respondents were coming from both rural and urban environment, however more than one third of respondents lived in the city and the rest of the in the countryside. As predicted, there were two dominant age groups. There were $39 \%$ of $20-30$-year-old respondents and $43 \%$ of people in the $30-40$-yearolds' group.

\section{Subject matter and frequency of talks in engagement period and marriage}

Communication, as mentioned earlier, plays a fundamental role in the process of building closeness between fiancés, spouses and all family members living in family community.

At the beginning of their life together, young couples often face many difficulties and sometimes they are unable to solve them together. This condition is often due to a little life experience as brides or young spouses, divergence in their values, as well as determining the boundaries between their own identity and personality with their partners. In order for a young marriage to function properly, partners have to understand each other, determine marital and family issues, flexibility, empathy but most of all they need to support each other.

In contrast, older, more experienced couples - equipped with some knowledge and life experience baggage, are more often able to solve problematic situations constructively. They also take a different perspective resolving conflicts, which arises from changing needs and new areas of marriage-family life. Communication 
in older marriages becomes more indirect, since partners have already experienced their habits, faults and behaviours. Most of the information provided in the course of marital communication is contained in the recipient-spouse, as well as the context of his speech. Much less in the content itself. Such situations reveal the tendency to build high context communication system between spouses. Communication clarity appears together with strong ties and intimacy after many years of partners' experience.

Guided by these premises the author wanted to know what the conversational subject matter is at different stages of marriage-family life. It was assumed that the conversations topics undertaken in the course of communication depend on the relationship's length, thus on the respondents experience. Therefore, both groups of respondents were questioned about marriage and fiancés communication issues. Respondents could use a prepared set of responses or add their own. They were also asked to describe the course of selected spouses or fiancés' communication, of their own choice. The following tabulation shows empirical data resulting from the research.

Table 1. Conversational subjects undertaken between married partners and fiancés

\begin{tabular}{|l|l|l|l|l|l|l|}
\hline \multirow{2}{*}{ Topics discussed with life partner } & \multicolumn{3}{l|}{$\begin{array}{l}\text { In total } \\
\mathrm{N}=100\end{array}$} & \multicolumn{2}{l|}{$\begin{array}{l}\text { Fiancés } \\
\text { N=50 }\end{array}$} & \multicolumn{2}{l|}{$\begin{array}{l}\text { Spouses } \\
\text { N=50 }\end{array}$} \\
\cline { 2 - 7 } & r.no & $\%$ & r.no & $\%$ & r.no & $\%$ \\
\hline About everyday difficulties & 89 & 89,0 & 46 & 92,0 & 43 & 86,0 \\
\hline About life plans & 71 & 71,0 & 44 & 88,0 & 27 & 54,0 \\
\hline About work & 65 & 65,0 & 42 & 84,0 & 23 & 46,0 \\
\hline About feelings & 60 & 60,0 & 40 & 80,0 & 20 & 40,0 \\
\hline About needs & 59 & 59,0 & 38 & 76,0 & 21 & 42,0 \\
\hline About family, children & 54 & 54,0 & 23 & 46,0 & 31 & 62,0 \\
\hline About health & 52 & 52,0 & 34 & 68,0 & 18 & 36,0 \\
\hline About their concerns and fears & 50 & 50,0 & 30 & 60,0 & 20 & 40,0 \\
\hline About intimate life & 48 & 48,0 & 28 & 56,0 & 20 & 40,0 \\
\hline About interest & 48 & 48,0 & 30 & 60,0 & 18 & 36,0 \\
\hline About mutual expectations & 45 & 45,0 & 27 & 54,0 & 18 & 36,0 \\
\hline About religious life & 24 & 24,0 & 20 & 40,0 & 4 & 8,0 \\
\hline $\begin{array}{l}\text { About appearance, fashion, } \\
\text { clothes }\end{array}$ & 21 & 21,0 & 18 & 36,0 & 3 & 6,0 \\
\hline About politics & & & & & & \\
\hline Other & 12 & 12,0 & 11 & 22,0 & 1 & 2,0 \\
\hline
\end{tabular}

Source: own research. Multiple choice test.

The tabular material indicates that there are various topics appearing in the process of exchanging thoughts and emotions between fiancés and spouses. 


\section{Barbara Lulek}

Categorization according to individual's functioning sphere criterion highlighted a few family communication areas on various stages of marriage-family life. They were called as follows:

1. Conversations concerning partners' intimate life, including getting to know each other in terms of their needs, feelings, emotions, as well as building and regulating intimacy in marriage and engagement period.

2. Conversations devoted to inter-familiar relations, as well as family members' acting manners, as a possibility to solve problems and difficulties revealed in the community and working out common ground in controversial issues concerning bringing up children.

3. Conversations concerning understanding the surrounding world, devoted to exchanging ideas on the social, economic, political, cultural and religious phenomena and processes.

As expected on the basis of subject literature, the topics circles outlined above reflect both groups' views differences. These circles were discussed with respect to respondents' indications number. Therefore, the first topics area focuses on the interfamily relationships, which included discussions devoted to the family daily affairs, communication difficulties occurring in the field, the information related to their own offspring, as well as conversations about life plans. According to the largest group of respondents, conversations issues focus on everyday life difficulties and ability to cope with them (spouses $-86.0 \%$ of respondents, fiancés $-92.0 \%$ of respondents). According to these two groups, in order to define life problems, as well as to show how complex they are, later, to negotiate probable solutions and to show the commitment in overcoming the difficulties, partners are required to do certain actions. It is quite difficult to achieve such a state. Respondents stress that ,it is a standard procedure that is not always possible to achieve. Of course, it is assumed that the relationship is a place for intimacy, closeness, mutual appreciation of the partners in difficult situations. But life carries many unpredictable situations and events that knock us out of these beautifully balanced roles in marriage" (Questionnaire no. 25, F., age 37, spouse).

This statement is a perfect preview for the next theme circle, which is discussed by nearly two third of spouses and only $46 \%$ of fiancés. The obtained data seem obvious, since only marriages turned into families undertake a number of new tasks and responsibilities. Families often undertake topics related to creating proper conditions for development and upbringing to their child and later to their children. Once having their offspring, parents are obliged to redefine their attitudes toward their child and refer to their ability to live together as spouses in new circumstances - taking care of the child. Spouses-respondents' conversations in this topics' area relate to sharing responsibilities over child care, establishing one pattern of responding to child's behaviour, parenting styles, creating favourable 
family home atmosphere, creating circumstances and acting to form a bond with the child and strengthen relationship with the spouse. Having a family and children is for engaged rather a conversation of the future. Unfortunately, over half of fiancés drop discussion on that topic focusing on their intimate feelings and experiences. After all, family aspirations which take the form of desires or intentions regarding the most appropriate time to start a family, number of children, ways of upbringing and relations in the family are very important, and sometimes controversial area of marital communication. Therefore, the author considers it reasonable that the preparation for marriage and family life should include conversations confronting both partners' future visions of marriage.

There are some significant differences related to conversations about future plans when comparing sentences from the second circle of both respondents' groups. The vast majority of fiancés $-88.0 \%$ of respondents declare conversations about such issues with a partner, while among spouses this ratio amounts to $54.0 \%$. Quite apparent diversity in both groups' views is probably due to married life stabilization. Unlike engaged pairs drawing their life plans, couples with many years of marital experience functioning in early adulthood already put them into practice. Thus, tasks such as selecting a spouse, learning to cooperate with a spouse, starting a family, or bringing up children and functioning in family, professional and social life is consistently implemented by married couples.

A large group of respondents characterizing their conversation with their fiancés or spouses locates them in a circle of intimate stories about relationships between close people, as they attempt to build a relationship with a partner on levels of co-understanding, common sense and cooperation. Respondents indicate that marriage and family are communities based on feelings revealed in conversations, however, only $40 \%$ of spouses-respondents converse about their feelings while in fiancés group the percentage is twice as much $-80 \%$. There is a similar situation in all categories assigned to that theme circle. Thus, fiancés more often talk about their own needs, concerns, fears, interests, their own expectations, about the health and intimate life than spouses. M. Braun-Gałkowska and M. Ryś write that this condition most likely stems from the recognition that marriage intention combines with forming expectations toward marriage and family, expectations towards partners which motivate to take action, increase feelings intensity intensify the desires and keep the partners highly involved in the relation [Braun-Gałkowska 1985, p. 125; Ryś 1999, p. 55]. These views are reflected in the following fiancés' statements who write: ,we share a great feeling which is love”, „it's all about my fiancé, I love him and I want to be with him”, „I did everything to get the intended of my heart”, „, my fiancé fascinates me”, „together we will get anything and we will succeed", ,we care about each other and help each other" (questionnaire 51, 60, 67, 76, 82, 93, fiancés). The vast majority of 


\section{Barbara Lulek}

engaged interviewees' statements reflect a strong fascination with the partner and the person indicates subordination of all activities to common goals. Hence, brides and grooms seek to meet each other's needs, support each other, they seem to be oblivious to the reality surrounding them as they are introverted and utterly in love. The most important for engaged respondents is often to be with the person they chose.

In the context of the data the following question should be formulated: Do conversations about feelings, needs, fears and anxieties stop being crucial for experienced marriages? Trying to answer the formulated problem, the author refers to both the subject literature and respondents opinions. A kind of youthful fascination period has already passed for marriages with years of experience. Spend many years of life together favours building relationships on solid foundations.

There are many situations when the spouses do not have to articulate some topics as most of the transmitted information is contained in the recipient - the spouse and the conversation's context and only a small part of it is encoded in the transmitted message. Such marriages communication becomes more indirect since partners have already experienced their habits, faults and behaviours. Status quo is confirmed by the following statements: „Today we talk differently than before. We know each other well, sometimes a gesture means more than words" (questionnaire 7, M., age 41, a spouse), "we talk about feelings and needs but without unnecessary excitement, I believe we are more matured and these become typical conversations, often accompanying by other" (questionnaire 43, M., age 39, a spouse), "after fifteen years the feelings are clear, needs known, expectations are realistic, they are not leading topics, they appear among others. But I remember that I used to be able to talk about it with my spouse for hours" (12 questionnaire, F., age 40, a spouse).

To sum up the discussion about fiancés and spouses' conversations topics, it is necessary to analyse conversations about the phenomena and social, economic, political, cultural and religious processes. The research material leads to the conclusion that only economic issues, especially professional work become relatively frequent subject while information exchange between partners. Nearly two thirds of respondents talk about their workplace in marriage-family life. In the engaged respondents' group the ratio is $84 \%$ while in the spouses' group the ratio is almost a half lower. Married respondents emphasize that stable economic situation forms the basis for a properly functioning family. However, they also indicate commonly occurring instability in the labour market, the threat of losing their jobs, increasing workers' flexibility and stress often occurring in the workplace. Surveyed spouses reported that family conversations often refer to these issues. In contrast, engaged interviewees look at a paid work a bit differently. They see work in terms of obtaining and maintaining employment consistent 
with their expectations. Fiancés declare substantial mobility and flexibility in the labour market, also writing that conversations often refer to developing their own business.

Only a quarter of respondents in total, including $40.0 \%$ of fiancés talk about religious matters, mainly focusing their conversations on identifying religious affiliation, and the marriage rite. Similarly, discussions devoted to defining political sympathies and antipathies apply only to $12.0 \%$ of all respondents.

In order to broaden the discussed research issues, the author of the report wondered if the frequency of communication acts is varied by the stage of marriage-family life. Therefore, the questionnaire contained a question relating to the frequency of conversations to both groups of subjects.

Table 2. The frequency of conversations between married partners and engaged partners

\begin{tabular}{|l|l|l|l|l|l|l|}
\hline \multirow{2}{*}{ Conversation's frequency } & \multicolumn{3}{l|l}{$\begin{array}{l}\text { In total } \\
\mathrm{N}=100\end{array}$} & \multicolumn{2}{l|}{$\begin{array}{l}\text { Fiancés } \\
\mathrm{N}=50\end{array}$} & \multicolumn{2}{l|}{$\begin{array}{l}\text { Spouses } \\
\mathrm{N}=50\end{array}$} \\
\cline { 2 - 8 } & r. no & $\%$ & r. no & $\%$ & r. no & $\%$ \\
\hline Very of ten & 57 & 57,0 & 33 & 66,0 & 24 & 48,0 \\
\hline Often & 34 & 34,0 & 16 & 32,0 & 18 & 36,0 \\
\hline Only when needed & 6 & 6,0 & 1 & 2,0 & 5 & 10,0 \\
\hline Rarely & 3 & 3,0 & - & - & 3 & 6,0 \\
\hline Very rarely & - & - & - & - & - & - \\
\hline In Total & 100 & 100,0 & 50 & 50,0 & 100,0 & 100,0 \\
\hline
\end{tabular}

Source: own research.

The basis for a happy and successful engagementand marriage is communication, in the course of which partners work out strategies and communication styles. Couples deal with disagreements, opinion differences, they negotiate and manage conflicts only by doing so. Conversation acts' frequency significantly influences these processes efficiency. Unsatisfactory information transfer between partners encourages hostility, lack of respect and conflict. In this sense, the obtained data should be assessed as positive. A small percentage of respondents $-3.0 \%$ indicate that the contact the heir partner is rare and it applies to people who are married. Nearly two thirds of engaged respondents and almost half of the spouses-respondents declare very frequent contacts with the partner and a third of all respondents identified their contacts in marriage-family life as frequent.

To sum up, interviewees statements confirm that conversations' topics change due to the changing marriage-family life stages. Young couples, still engaged, concentrate their discussions on getting to know each other, developing their interests, talking about feelings, identifying and meeting their needs, verbalising their expectations towards partner and getting married and building a family. 


\section{Barbara Lulek}

Fiancés are also familiar with issues related to everyday life difficulties, professional work and religious life. They undertake these issues in the conversations in order to get to know their partners or making the right choice of fiancé and future spouse. Fiancés' conversations are rather impulsive, spontaneous and focusing on feelings - love in particular. Engaged subject usually inform their partners about their internal states through verbal messages. In case of experienced married couples the conversations' subject focus on selected thematic circles, especially inter-family life, including everyday life difficulties and how to resolve them, children and their upbringing, life plans mainly related to their own children, as well as professional work. Marriage roles revealed in repeated interactions are executed basing on undertaken conversations' subjects, often in an indirect way. The information contained in the receiver acquires some meaning.

\section{Fiancés and spouses communicational barriers}

M. Ryś writes that engagement period with marriage perspective combines with inner maturity [Ryś 1999, p. 37]. To act in a mature way, regardless from the relationship people stay in, whether it is a marriage or engagement, means to inhibit and to trigger partner's feelings, as well as a self-control while making decisions. It allows prioritizing matters, achieving emotional stability, as well as building moral support and ability to sustain spouses' tension. Despite these assumptions, it is clear that marriage or family functioning combines with emerging conflicts. Disagreements are inevitable especially when partners have different expectations.

Disagreements appearing in relationship may have various background like family life, partners' life, honoured values, behaviours, access to partner's resources or ways of realizing common goals. In time, partners may realize that as personality develops they may verbalize other needs and desires or they may have different ideas for a home budget, upbringing children or life plans [Plopa 2005, pp. 120-122]. Family and marriage communication disorders can take various forms, have different scope and severity [Harwas-Napierała 2008, p.109].

Guided by these premises, the author wanted to recognise what barriers and difficulties are engaged and married partners endangered to. The questionnaire included an open question which would allow the interviewees to put their free thoughts about factors limiting marital and engaged partners' communication. Respondents' free statements were classified in order to single out the following factors' groups: personal, situational and related to communicational style. 
Table 3. Communication barriers in married and engaged couples' relations

\begin{tabular}{|c|c|c|}
\hline Factors & Fiancés communication & Married couples' communication \\
\hline Personal & $\begin{array}{l}\text { Jealousy } \\
\text { Insincerity } \\
\text { Cheating } \\
\text { Distrust } \\
\text { Pessimism } \\
\text { Stubbornness }\end{array}$ & $\begin{array}{l}\text { Jealousy, insincerity, distrust } \\
\text { Intolerance } \\
\text { High-flying partner } \\
\text { Hiding feelings } \\
\text { Impatience } \\
\text { Disapproval } \\
\text { Lack of criticism } \\
\text { Distinct characters }\end{array}$ \\
\hline $\begin{array}{l}\text { Related to the } \\
\text { communicational } \\
\text { process }\end{array}$ & $\begin{array}{l}\text { Reproaches } \\
\text { Understatements } \\
\text { Interrupting speech } \\
\text { Instructing } \\
\text { Inability to compromise } \\
\text { One partner's desire to dominate } \\
\text { Inadequate ways of solving conflicts }\end{array}$ & $\begin{array}{l}\text { Reluctance to talk-no problem } \\
\text { No conversation } \\
\text { Interrupting speech, } \\
\text { understatements } \\
\text { Instructing, sarcasm } \\
\text { Inability to compromise } \\
\text { One partner's desire to dominate } \\
\text { Inadequate ways of solving conflicts }\end{array}$ \\
\hline Situational & $\begin{array}{l}\text { Lack of money } \\
\text { Lack of time } \\
\text { Unemployment } \\
\text { Stress } \\
\text { Going abroad } \\
\text { The interference of others } \\
\text { Disapproval in fiancé's family }\end{array}$ & $\begin{array}{l}\text { No time for each other } \\
\text { Different hobbies } \\
\text { Accommodation shared with } \\
\text { parents } \\
\text { Disapproval in the family of origin } \\
\text { Lack of financial means } \\
\text { Unreasonably long separation }\end{array}$ \\
\hline
\end{tabular}

Source: own research.

Indicated by both fiancés and spouses, the first separated factors' group are factors determining personality. According to the respondents, the main difficulties during conversations arise from the personality traits of both the sender and the recipient. Spouses call that characters' incompatibility. In the literature from the field of marriage counselling there is wide information about the divergence of expectations and building an idealized spouse's image as unfavourable processes for marriage. To characterise unfavourable features in details, engaged interviewees mention jealousy, distrust and insincerity. These features indicate the difficulties that occur between partners at the stage of determining the marital boundaries which allow to build good relations with family, friends and colleagues. They also define both partners' satisfactory loyalty attitude to their expectations. It is unfavourable for building a marriage or a family when partners are too precise in setting the boundaries in contacts with others, as well as when they to freely interpret contacts with people from outside the family. Tested spouses add intolerance to it, sometimes a high-flying partner and lack of criticism towards each other. Both delimit the boundaries too close contact with others, and too 
freely is not conducive to building a marriage and family. Respondents spouses even add that the importance of the lack of understanding, and sometimes exaggerated ambitions of one of the partners and the lack of criticism of each other. What is interesting, both groups' statements localize unwanted personality traits in their partner's character. Impatience and lack of acceptance were also pointed out as significant in marriage communication process. Respondents emphasize that the basic condition for the effective information exchange is to carefully and patiently listen to people with whom the discussion is taken up. Speaker's unconditional acceptance, empathic understanding and openness are also extremely important in such situations, which are impossible to obtain when a person is insincere or intolerant. Therefore, it must be emphasized that except for personality factors impeding exchanging thoughts, feelings, emotions, the respondents signify disrespect for partner's dignity, which is a clear distancing from the interlocutor's world of experience.

The second group of factors has been described as typical disorders and errors associated with the communication process. The basic difficulties in the distinct category are situations related to lack of communication in the relationship or denial. Married respondents reported that the desire to downplay the problem or attributing it a low importance mostly make it return with a double strength. Underestimating problems like interrupting the speaker's talk leads to imposing new topics, focusing on own issues, as well as losing the conversation partner out of sight. Both groups of respondents also highlighted the lack of ability to compromise, which connects to domination strategy and non-partner style of communication which is sometimes accompanied by instructing, sarcasm and biting humour. It also emphasizes one of the interlocutors leading role, destroys confidence and hurts partner in a way that is difficult to heal.

Finally, the last group of factors hindering marriage and fiancés communication. The author included to the group barriers resulting from a complex family, economic and cultural situation. The respondents' statements gathered in the course of research emphasized that unemployment and destabilisation on labour market, as well as unfavourable housing conditions - living with extended family, i.e. outsiders interfering in the relationship, involving excessively in activities outside the family and common lack of time for each other, are significant for marriage and fiancés communication process.

All these factors contribute to appearing dysfunctional patterns of communication in marriage-family life. Obviously they appear in conflict situations but they also include signs of manipulation, focusing on partners' own needs, and inconsistent information. 


\section{Conclusion - a few remarks on model communication between partners}

Communicational need in the family is something obvious and durable, however its form changes due to different stages of family life. The reason is that the feature of family functioning is constant variability in relationship, life situation, behaviour and ability to adapt and accommodate the changes. Each family member is both the sender and receiver of verbal and non-verbal messages accompanied by a specific situational context, emotions associated and adopting appropriate attitude [Rostowska 2008, p. 89]. Properly run communication deepens family ties, a sense of community, intimacy, increases mutual understanding and favours frequent information exchange rewarding spouses and engaged couples. It becomes the basic means of constructive solutions to problems. Such communications base on clear and legible messages sent and received between two open and sincere partners revealing authentic positive and negative experiences.

1. The analysis of collected information about conversations' frequency and subject matters between fiancés and spouses with fifteen years of experience derives the following conclusions:

2. Conversations run by experienced spouses and young couples include similar issues focusing on intimate experience, family community functioning, as well as marriage and engaged couple's place in society and culture. However, young couples' conversations more often concern feelings, needs, expectations, life plans and current problems in the relationship. Mutual ideas exchange between spouses with many years of experience focus on interfamily life, mainly, on situations and circumstances affecting family members, especially children, as well as their offspring's life plans and aspirations.

3. Frequency of communication acts carried out in the study groups is satisfactory. Only a few spouses - a small percentage of respondents communicate with each other rarely which leaves partners' needs unfulfilled. Most of the respondents assessed the relationship communication as frequent or very frequent.

4. According to respondents, main factors hindering marital communication process are personality factors like insincerity, jealousy, stubbornness, impatience and lack of acceptance, as well as committing common communication errors resulting from the tendency to dominate in communication process and situational due to the complex family social and economic conditions. 


\section{Barbara Lulek}

\section{Bibliografia}

Argyle M. (1999), Psychology of interpersonal relations, PWN Scientific Publishing House, Warsaw.

Braun-Gałkowska M. (1985), Active love. Psychological determinants of successful marriage, Pax Publishing, Warsaw.

Denek K. (2002), Sources of didactics' weaknesses and attempts to overcome them [in] edit. A.Karpińska, Education in dialogue and reform, Trans Humana Publishing, Białystok.

Dobek-Ostrowska B. (2004), Basics of social communication, PWN Scientific Publishing House, Wroclaw.

Dobek-Ostrowska B. (2006), Political and Public Communication, PWN Scientific Publishing House, Warsaw.

Domachowski W. (1993), Social Psychology of non-verbal communication, Edytor Publishing, Toruń.

Filipiak M. (2004), Homo Communicans, introduction to the theory of mass communication, UMCS Publishing, Lublin.

Głodowski W. (2001), Interpersonal Communication, Hansa Communication Publishing, Warsaw.

Harwas- Napierała B. (2008), Interpersonal Communication in the family, UAM Scientific Publishing House, Poznan.

Kiezik-Kordzińska E. (2004), School of dialogue, WSiP Publishing, Warsaw.

Laskowski J. (1985), Marriage and family, Pax Publishing, Warsaw.

McKay M., Davis M., Fanning P. (2004), Art of effective communication, Psychological Publishing of Gdansk, Gdansk.

Morreale S.P., Spitzberg B.H., Barge J.K. (2007), Communication between people. Motivation, knowledge and skills, PWN Scientific Publishing House, Warsaw.

Mrozowski M. (2001), The mass media, Aspra-Jr Publishing, Warsaw.

Muszyński W., Sikora E. (2008), Love, loyalty and honesty at the crossroads of the present, shapes of contemporary family, Adam Marszałek Publishing, Torun.

Nęcki Z. (1992), Interpersonal Communication, Ossoliński National Institute Publishing, Wroclaw.

Pisarek W. (2008), Introduction to the communication science, Academic and Professional Publishing, Warsaw.

Plopa M. (2008), Marriage and family ties, „Impuls” Publishing House, Krakow.

Poręba P. (1981), Psychological aspects of family life, Pax Publishing, Warsaw.

Rostowska T. (2008), Marriage, family, work and quality of life, „Impuls” Publishing House, Krakow.

Rutkowiak J. (1992), The question, dialogue, education, PWN Scientific Publishing House, Warsaw. 
Ryś M. (1999), The outline of marriage psychology, Methodological Centre of PsychologicalPedagogical Counselling, Ministry of National Education, Warsaw.

Stewart J., Logan C. (2003), Verbal Communication, [in:] edit. J. Stewart, Bridges instead of walls. Handbook of interpersonal communication, PWN Scientific Publishing House, Warsaw.

Tarnowski J. (1991), The man - Dialogue - Education, "Znak", 9.

Winiarski M. (2000), The meaning and dimensions of interpersonal dialogue [in:] edit. T. Pilch, The need for dialogue between cultures and people, „Żak” Publishing, Warsaw.

Zielonacki A. (1982), The marriage, Ossolineum Publishing, Wroclaw. 